\title{
Analisis Yuridis Mengenai Pentingnya Klausula Pilihan Hukum dan/atau Pilihan Forum dalam Kontrak Bisnis Internasional
}

\author{
Michael Saputra Prajugo, Fakultas Hukum Universitas Surabaya, email: \\ michaelsaputraprajugo234@gmail.com
}

\begin{abstract}
One sphere regulated by International Civil Law is international business contracts which contain foreign elements. The existence of foreign elements in international business contracts is followed by the emergence of the freedom of the parties to determine choice of law and/or choice of forum. Without the inclusion of choice of law and/or choice of forum clauses, problems will arise about which country's law applies and which forum is authorized to resolve international business contract disputes. One important thing related to choice of law and/or choice of forum in international business contracts is the limitations toward them. The research question is what are the limitations toward choice of law and/or choice of forum in international business contracts?. The research method used is juridical normative with statute approach and conceptual approach as problem approaches. The result of the research explicates in general, the limitations toward choice of law and/or choice of the forum in international business contracts are the limitations determined in Article 1339 of the Civil Code namely not contrary to propriety, customs, laws, and applicable legal system in every country. The parties need to understand the limitations toward choice of law and/or choice of forum clauses in international business contracts and implement them when making choice of law and/or choice of forum clauses so these clauses are not null and void.
\end{abstract}

Keywords: "choice of law", "choice of forum", "international business contracts".

\section{Pendahuluan}

Kehidupan masyarakat tidak terlepas dari hubungan hukum antara subjek hukum. Hubungan hukum dapat dibedakan menjadi hubungan hukum bersifat privat dan hubungan hukum bersifat publik (Marzuki, 2008). Hubungan hukum para pihak telah menembus batas-batas negara yang menyebabkan para pihak terlibat dalam suatu hubungan hukum yang disebut sebagai hubungan Hukum Perdata Internasional. Hukum Perdata Internasional merupakan bagian dari hukum perdata dalam lingkup nasional. Istilah internasional merujuk pada unsur asing dalam hubungan dan peristiwa hukum di bidang keperdataan yang mengandung unsur asing. Dengan demikian, Hukum Perdata Internasional bukan merupakan bagian dari hukum internasional. Hal ini dapat ditinjau dalam pengertian Hukum Perdata Internasional yang dikemukakan oleh Gautama (1977), yaitu keseluruhan peraturan dan keputusan hukum yang menunjukkan stelsel hukum manakah yang berlaku atau apakah yang merupakan hukum. Dalam Hukum Perdata Internasional dikenal titik taut primer dan titik taut sekunder (Khairandy, 2007).

Salah satu bidang yang diatur oleh Hukum Perdata Internasional adalah kontrak bisnis internasional. Kontrak bisnis internasional merupakan bagian dari kontrak internasional, yaitu kontrak yang di dalamnya terdapat unsur asing (Gautama, 1976). Kontrak bisnis internasional merupakan kontrak privat antara orang perseorangan maupun antara badan hukum. Unsur asing dalam kontrak bisnis internasional, menurut Hardjowahono (2013), diikuti dengan munculnya elemen pokok lain yang sangat 
penting yaitu kebebasan para pihak untuk melakukan pilihan hukum dan/atau pilihan forum. Dikutip dari Adolf (2010), perlunya pencantuman klausula pilihan hukum dan/atau pilihan forum dalam kontrak bisnis internasional masih menjadi perdebatan antara dua orang sarjana hukum. Huala Adolf berpendapat sifat pilihan hukum tidak merupakan prasyarat untuk sahnya suatu kontrak. Di sisi lain, Clive M. Schmitthoff berpendapat suatu kontrak internasional yang tidak ada pilihan hukumnya adalah kontrak yang cacat. Era perdagangan bebas membuat negara-negara di dunia seolah-olah tanpa batas dalam bidang perdagangan internasional. Permasalahan umum dalam perdagangan internasional adalah penerapan peraturan hukum negara yang berbeda, khususnya jika salah satu negara tidak mengakui hukum nasional negara asing (Soemali dan Yulyanti, 2010). Oleh karena itu, diperlukan harmonisasi peraturan dalam hukum kontrak dagang internasional. Dalam perdagangan internasional, para pihak harus memperhatikan budaya hukum masing-masing pihak, salah satunya adalah kontrak dagang internasional yang isinya mengikat para pihak. Pada dasarnya, para pihak selalu menghendaki hal-hal yang telah disepakati dan dituangkan dalam kontrak dapat dipatuhi dan dilaksanakan sesuai dengan tujuan diadakannya kesepakatan dalam kontrak. Meskipun demikian, seringkali sengketa tetap saja terjadi.

Dalam perdagangan internasional, perbedaan aturan hukum nasional para pihak dikhawatirkan mempengaruhi kelancaran perdagangan (Adolf, 2005). Salah satu langkah antisipasi yang dilakukan para pihak adalah mencantumkan klausula pilihan hukum dan/atau pilihan forum dalam kontrak bisnis internasional. Namun, tidak tertutup kemungkinan para pihak tidak mencapai kesepakatan sehingga para pihak tidak mencantumkan klausula pilihan hukum dan/atau pilihan forum dalam kontrak yang dibuat. Tanpa pencatuman klausula pilihan hukum dan/atau pilihan forum, akan muncul permasalahan tentang hukum negara mana yang berlaku dan forum mana yang berwenang untuk menyelesaikan sengketa kontrak bisnis internasional.

Salah satu hal penting tentang pilihan hukum dan/atau pilihan forum dalam kontrak bisnis internasional yang menarik untuk diteliti adalah batasan-batasannya. Batasan merupakan rambu-rambu bagi para pihak dalam menentukan pilihan hukum dan/atau pilihan forum dalam kontrak bisnis internasional. Berdasarkan latar belakang masalah yang telah diuraikan di atas, maka rumusan masalah dalam penelitian ini adalah: Apa saja batasan-batasan terhadap pilihan hukum dan/atau pilihan forum dalam kontrak bisnis internasional?

\section{Pembahasan}

Definisi hukum internasional, menurut Parthiana (2003), adalah sekumpulan hukum yang sebagian besar terdiri atas prinsip-prinsip dan peraturan-peraturan yang mengatur tentang perilaku yang harus ditaati oleh negara-negara dan oleh karena itu juga harus ditaati dalam hubungan-hubungan antara mereka satu dengan lainnya, serta yang juga mencakup organisasi internasional, hubungan antara organisasi internasional satu dengan lainnya, hubungan peraturan hukum yang berkenaan dengan fungsi lembaga atau antara organisasi internasional dengan negara atau negara-negara, dan hubungan antara organisasi internasional dengan individu atau individu. Pasal 38 ayat (1) Statuta Mahkamah Internasional menentukan sumber hukum internasional yang digunakan Mahkamah Internasional dalam mengadili perkara antara lain:

\section{a. Perjanjian Internasional}

Menurut Mauna (2010), meliputi perjanjian internasional bersifat umum dan bersifat khusus. Perjanjian internasional merupakan sumber utama hukum internasional. Perjanjian internasional dapat berbentuk bilateral, regional, dan universal. Konvensi atau perjanjian internasional yang merupakan sumber utama hukum internasional adalah konvensi yang berbentuk law making treaties, yaitu perjanjian-perjanjian internasional yang berisikan prinsip- 
prinsip dan ketentuan-ketentuan yang berlaku umum yang dirumuskan oleh negara-negara sebagai pegangan dalam melaksanakan kegiatan dan hubungannya satu sama lain;

b. Kebiasaan Internasional

Menurut Mauna (2010), hukum kebiasaan internasional berasal dari praktik negaranegara, yaitu melalui sikap dan tindakan yang diambil oleh negara-negara terhadap suatu persoalan. Hukum kebiasaan terbentuk dengan didasari oleh praktik yang sama, dilakukan secara konstan, tanpa adanya pihak yang menentang, dan diakui oleh banyak negara;

c. Prinsip-Prinsip Umum Hukum Yang Diakui Oleh Negara-Negara Beradab

Sumber hukum berupa prinsip-prinsip umum hukum merupakan prinsip umum hukum yang berlaku dalam seluruh atau sebagian besar hukum nasional negara-negara. Prinsip-prinsip umum yang diambil dari sistem-sistem hukum nasional dapat mengisi kekosongan hukum internasional (Mauna, 2010)

d. Keputusan pengadilan dan pendapat para ahli yang telah diakui kepakarannya

Menurut Mauna (2010), kedua sumber ini merupakan sumber tambahan hukum internasional. Keputusan pengadilan memainkan peran yang cukup penting dalam membantu pembentukan norma-norma baru hukum internasional, dimana keputusan pengadilan yang dimaksud adalah keputusan Mahkamah Internasional.

Selain bidang hukum internasional yang telah diuraikan di atas, terdapat bidang hukum perdagangan internasional yang khusus mengkaji aktivitas perdagangan lintas negara. Menurut Adolf (2005), terdapat enam sumber hukum dalam perdagangan internasional, yaitu:

a. Perjanjian internasional : perjanjian internasional terbagi dalam tiga bentuk, yaitu perjanjian multilateral, perjanjian regional, dan perjanjian bilateral;

b. Hukum kebiasaan internasional, yakni praktek-praktek para pedagang yang dilakukan berulang-ulang sehingga kebiasaan yang berulang-ulang dengan waktu yang relatif lama tersebut menjadi mengikat. Sumber hukum kebiasaan internasional disebut sebagai lex mercatoria;

c. Prinsip-prinsip hukum umum, yakni sumber hukum ini akan mulai berfungsi ketika hukum perjanjian internasional dan hukum kebiasaan internasional tidak memberikan jawaban terhadap persoalan. Contoh prinsip-prinsip hukum umum antara lain : prinsip itikad baik, prinsip pacta sunt servanda, dan prinsip ganti rugi;

d. Putusan-putusan badan pengadilan dan doktrin, yakni putusan badan pengadilan memiliki fungsi dan peran pelengkap seperti prinsip-prinsip hukum umum. Peran dan fungsi doktrin adalah menjelaskan suatu hukum perdagangan internasional dan menemukan hukum;

e. Kontrak, yakni sumber utama dan terpenting dalam perdagangan internasional adalah kontrak yang dibuat oleh para pedagang sendiri. Oleh karena kontrak dibuat oleh para pedagang sendiri, kontrak berlaku sebagai undang-undang bagi para pihak;

f. Hukum nasional, yakni ketika terjadi sengketa, pengadilan atau arbitrase terlebih dahulu akan melihat klausula pilihan hukum dalam kontrak. Selain itu, peran signifikan dari hukum nasional lahir dari yurisdiksi atau kewenangan negara yang bersifat mutlak dan eksklusif.

Dalam perdagangan internasional, para pihak tunduk pada sistem hukum negara yang berbeda. Sistem hukum negara yang berbeda memiliki pengaturan berbeda, misalnya tentang prinsip kebebasan berkontrak dan prinsip itikad baik yang dikenal dalam kontrak bisnis internasional. Berikut uraian tentang perbedaan pengaturan prinsip antara negara-negara:

a. Prinsip kebebasan berkontrak, yakni negara Amerika Serikat lebih memberikan kebebasan 
bagi para pihak dibandingkan negara Inggris. Hukum negara Amerika Serikat menerima proper law of contract berdasarkan pilihan para pihak selama memiliki hubungan yang masuk akal dengan transaksi dan untuk menghindari konflik sistem hukum negara Amerika Serikat memiliki yurisdiksi atau arbitrase yang netral (Vishal, 2016);

b. Prinsip itikad baik, yakni negara Italia yang menganut civil law mengakui adanya kewajiban itikad baik oleh para pihak sebelum dan setelah kontrak ditandatangani. Sebaliknya, negara Inggris yang menganut common law tidak mengenal para pihak terikat oleh prinsip beritikad baik dalam proses negosiasi (Adolf, 2010). Upaya harmonisasi prinsip hukum antara negaranegara telah dilakukan oleh lembaga internasional dan diwujudkan dalam konvensi internasional. Contoh lembaga internasional yang dimaksud adalah The United Nations Commission on International Trade Law (UNCITRAL) dan The International Institute for the Unification of Private Law (UNIDROIT). Contoh konvensi internasional yang diwujudkan adalah The United Nations Convention on Contracts for the International Sale of Goods (CISG).

Berikut ditinjau syarat sah kontrak bisnis internasional:

a. UNCITRAL

dikutip dari Adolf (2005), UNCITRAL adalah badan kelengkapan khusus dari Majelis Umum PBB berkedudukan di Wina (Austria), yang dibentuk berdasarkan Resolusi Majelis Umum PBB Nomor 2205. Tugas utama UNCITRAL adalah mengurangi perbedaan-perbedaan hukum di antara negara-negara anggota yang dapat menjadi tantangan bagi perdagangan internasional dengan memajukan perkembangan harmonisasi dan unifikasi hukum perdagangan internasional secara progresif. Salah satu instrumen hukum yang dihasilkan UNCITRAL adalah Arbitration Rules of the United Nations Commission on International Trade Law yaitu Aturan Arbitrase Komisi Perserikatan Bangsa- Bangsa tentang Hukum Perdagangan Internasional. Pasal 1 Aturan Arbitrase UNCITRAL menentukan apabila para pihak dalam suatu kontrak telah menyetujui secara tertulis perselisihan sehubungan dengan kontrak tersebut akan dirujuk ke arbitrase berdasarkan Aturan Arbitrase UNCITRAL, perselisihan akan diselesaikan sesuai dengan Peraturan ini dengan tunduk pada modifikasi yang para pihak dapat menyetujui secara tertulis. Persetujuan adalah wujud kesepakatan para pihak. Berdasarkan Pasal 7 ayat 2 Aturan Arbitrase UNCITRAL, perjanjian arbitrase harus dibuat secara tertulis.

b. UNIDROIT

UNIDROIT adalah organisasi antar pemerintah independen berkedudukan di Roma (Italia) yang dibentuk berdasarkan The UNIDROIT Statute. Tujuan utama dibentuknya UNIDROIT adalah melakukan kajian untuk mengharmonisasi dan mengkoordinasikan hukum privat, khususnya hukum dagang di antara negara-negara (Adolf, 2005). Salah satu prinsip hukum kontrak UNIDROIT adalah prinsip kebebasan berkontrak. Menurut Suharnoko (2004), kehendak para pihak dapat dinyatakan dengan berbagai cara baik lisan maupun tertulis dan mengikat para pihak dengan segala akibat hukumnya. Pasal 1.1 UNIDROIT menegaskan adalah kebebasan para pihak untuk membuat kontrak, termasuk kebebasan untuk menentukan apa yang mereka sepakati (Adolf, 2010). Prinsip kontrak lain yang dikenal dalam UNIDROIT adalah prinsip konsensualisme, yang berarti bahwa dalam kontrak UNIDROIT kesepakatan para pihak merupakan hal yang mutlak untuk terbentuknya suatu kontrak walaupun tidak dibuat secara tertulis. Sebagaimana dikutip dari Adolf (2010), Pasal 1.10 pengertian tertulis suatu kontrak dirumuskan secara luas sebagai yang meliputi tanpa menggunakan kertas (Adolf, 2010). Pasal 3.1.2 UNIDROIT Principles 2010 Validity of Mere 
Agreement menentukan kontrak disimpulkan, dimodifikasi atau dihentikan hanya oleh kesepakatan para pihak, tanpa persyaratan lebih lanjut.

c. CISG

Dikutip dari BPHN (2013), CISG adalah suatu konvensi internasional yang disusun oleh Badan Perserikatan Bangsa Bangsa (PBB) dan dibuat melalui upaya diplomatik dari UNCITRAL.Pasal 4 CISG menegaskan konvensi tidak mengatur keabsahan kontrak atau setiap ketentuannya atau setiap penggunaannya. Pasal 11 CISG tidak mensyaratkan secara tegas kontrak harus tertulis., melainkan kontrak dapat dibuktikan dengan bukti saksi (Adolf, 2010). Walaupun kontrak bisnis internasional sah karena telah memenuhi syarat keabsahan kontrak, terdapat batasan-batasan pilihan hukum dan/atau pilihan forum dalam kontrak bisnis internasional. Menurut Kamus Besar Bahasa Indonesia, batasan adalah sesuatu yang ditentukan dan tidak boleh dilampaui.

Menurut Gautama (1987), batasan-batasan terhadap kebebasan para pihak dalam menentukan pilihan hukum adalah sebagai berikut:

a. Pilihan hukum hanya dibenarkan dalam bidang hukum kontrak, bidang hukum lain, misalnya hukum keluarga tidak dapat diadakan pilihan hukum;

b. Pilihan hukum tidak boleh mengenai hukum yang bersifat memaksa : tidak boleh diadakan untuk perjanjian yang diadakan oleh pemerintah untuk mengatur hukum perdata dengan ciri hukum publik, sebagai contoh perjanjian di bursa dan perjanjian kerja;

c. Pilihan hukum tidak boleh menjelma menjadi penyelundupan hukum: tidak boleh diadakan apabila dalam kontrak terdapat titik pertalian lain yang jauh lebih kuat daripada pilihan hukum.

Dikutip dari Adolf (2010), batasan-batasan terhadap kebebasan para pihak dalam menentukan pilihan hukum antara lain:

a. Tidak melanggar ketertiban umum : pembatasan ini umumnya dikenal di banyak sistem hukum, termasuk di dalam pengertian ini adalah undang-undang suatu negara dan putusan pengadilan;

b. Hanya di bidang hukum kontrak, artinya tidak di bidang hukum lainnya, misalnya hukum tata negara, hukum internasional, kontrak kerja, dan lain-lain;

c. Harus ada kaitan dengan kontrak bersangkutan, yakni pembatasan ini penting agar para pihak tidak menjadi semena-mena memilih hukum yang disepakati yang ternyata tidak ada kaitannya dengan kontrak yang mereka tandatangani;

d. Tidak untuk menyelundupkan hukum. Menyelundupkan hukum adalah mengenyampingkan, tidak mengindahkan suatu aturan hukum yang seharusnya berlaku;

e. Tidak untuk transaksi tanah atau hak-hak atas benda tidak bergerak. Transaksi tanah atau transaksi yang terkait benda tidak bergerak tidak dapat dipilih hukum selain daripada hukum di mana benda tidak bergerak tersebut berada;

f. Tidak boleh mengenai ketentuan hukum perdata dengan sifat publik. Sebagai contoh adalah status kewarganegaraan seseorang dan hubungan hukum di bidang keluarga;

g. Melanggar itikad baik, yakni pembatasan utama dari kebebasan para pihak dalam memilih hukumnya adalah adanya pengecualian tidak bertentangan dengan itikad baik, termasuk di dalamnya pilihan hukum yang bertentangan dengan tujuan hukum;

h. Pilihan hukum digunakan untuk menghindari tanggung jawab pidana yaitu para pihak tidak dapat menggunakan pilihan hukumnya untuk menghindari tanggung jawab pidana; 
i. Adanya aturan-aturan hukum yang sifatnya memaksa. Aturan hukum yang sifatnya memaksa diakui oleh hukum nasional pada umumnya, biasanya dikeluarkan oleh suatu negara untuk melindungi berbagai kepentingan sosial dan ekonomi;

j. Hukum substantif yang dipilih mengatur objek kontrak. Hukum yang dipilih oleh para pihak harus memang mengatur objek dari kontrak yang ditandatangani oleh para pihak.

Menurut Adolf (2010), batasan-batasan terhadap kebebasan para pihak dalam menentukan pilihan forum antara lain:

a. Tidak boleh ada unsur penipuan. Prinsip otonomi para pihak baru akan diakui apabila para pihak memang telah dengan itikad baik dan sepakat untuk memilih forum dalam kontrak yang dibuat;

b. Pembatasan kewenangan pokok perkara oleh pengadilan, yang dimaksud batas- batas kewenangan ini adalah pembatasan berdasarkan kompetensi absolut dari pengadilan;

c. Pembatasan kewenangan pengadilan terhadap pihak yang bersengketa, yakni pembatasan menyangkut kewenangan yang disandang badan peradilan tersebut;

d. Forum non-conveniens, alasan ini digunakan jika badan pengadilan yang dipilih beranggapan pengadilan lain lebih tepat mengadili sengketa dengan pertimbangan tertentu;

e. Tidak efektif atau tidak berfungsinya forum yang dipilih, kewenangan forum tertentu yang ditempuh mengingat forum yang dipilih oleh para pihak ternyata menjadi tidak efektif atau tidak mungkin melaksanakan fungsinya;

f. Tidak melanggar ketertiban umum, badan peradilan di negara Amerika Serikat tidak akan menghormati adanya pilihan forum negara asing apabila bertentangan dengan ketertiban umum di negara Amerika Serikat.

Kebebasan para pihak menentukan pilihan hukum dan/atau pilihan forum yang melahirkan kesepakatan tidak mutlak, melainkan terdapat batasan-batasan sebagai rambu-rambu agar kesepakatan tersebut mengikat sebagai undang-undang. Kebebasan ini tidak dipermasalahkan oleh negara-negara di dunia selama tidak melanggar sistem hukum nasional masing-masing negara. Contoh batasan terhadap pilihan hukum dalam negara-negara dapat ditinjau menggunakan contoh negara Belanda dan Amerika Serikat. Di negara Belanda, batasan pilihan hukum antara lain ketentuan mengenai tenaga kerja, lalu lintas devisa atau sejenisnya, dan ketertiban umum (Latip, 2002). Dikutip dari Vishal (2016), batasan pilihan hukum di negara Amerika Serikat adalah harus memiliki hubungan dengan kontrak dan tidak boleh bertentangan dengan ketentuan wajib hukum negara Amerika Serikat.

\section{Kesimpulan}

Pilihan hukum dan/atau pilihan forum dalam kontrak bisnis internasional didasarkan atas asas kebebasan berkontrak dan kesepakatan para pihak. Salah satu batasan yang harus diperhatikan oleh para pihak adalah sistem hukum dari masing- masing negara di mana kontrak tersebut dibuat, yang disesuaikan dengan aturan-aturan hukum internasional. Secara umum, batasan-batasan pilihan hukum dan/atau pilihan forum adalah batasan yang ditentukan dalam Pasal 1339 Kitab Undang-Undang Hukum Perdata yaitu tidak boleh bertentangan dengan kepatutan, kebiasaan, undang-undang, dan juga dengan sistem hukum yang berlaku di tiap-tiap negara.

Para pihak perlu memahami batasan-batasan pilihan hukum dan/atau pilihan forum dalam kontrak bisnis internasional dan mengimplementasikannya saat membuat klausula pilihan hukum 
dan/pilihan forum. Dengan demikian, klausula pilihan hukum dan/atau pilihan forum dalam kontrak bisnis internasional tidak bertentangan dengan peraturan perundang-undangan nasional suatu negara sehingga tidak batal demi hukum.

\section{Daftar Referensi}

Buku:

Arbitration Rules of the United Nations Commission on International Trade Law.

Badan Pembinaan Hukum Nasional. (2013). Naskah Akademik tentang Ratifikasi Konvensi PBB Mengenai Kontrak Jual Beli Internasional. Tersedia online dari: https://www.bphn.go.id/data/documents/na_bbm.pdf

Bayu Seto Hardjowahono. (2013). Dasar-Dasar Hukum Perdata Internasional. Bandung: Citra Aditya Bakti.

Boer Mauna. (2010). Hukum Internasional : Pengertian Peranan dan Fungsi Dalam Era Dinamika Global. Bandung: Alumni.

Huala Adolf. (2005). Hukum Perdagangan Internasional. Jakarta: Raja Grafindo Persada.

--oras (2010). Dasar-Dasar Hukum Kontrak Internasional Edisi Revisi. Bandung: Refika Aditama.

I Wayan Parthiana. (2003). Pengantar Hukum Internasional. Bandung: Mandar Maju.

Kamus Besar Bahasa Indonesia.

Peter Mahmud Marzuki. (2008). Pengantar Ilmu Hukum. Jakarta: Kencana Prenada Media Group.

Ridwan Khairandy. (2007). Pengantar Hukum Perdata Internasional. Yogyakarta: FH UII Press.

Soemali \& Lidya Noor Yulianti (2010). Penyelesaian Sengketa Melalui Arbitrase Dalam Investasi

Perdagangan. Jurnal Hukum, 18(18), 53-68.

Sudargo Gautama. (1976). Kontrak Dagang Internasional. Bandung: Alumni. Percetakan. . (1977). Pengantar Hukum Perdata Internasional Indonesia. Bandung: Rindang Mukti Unit

Suharnoko. (2004). Hukum Perjanjian : Teori dan Analisa Kasus. Kencana: Jakarta.

The International Institute for the Unification of Private Law.

The United Nations Convention on Contracts for the International Sale of Goods.

Vatsalya Vishal. (2016). Choice of Law and Choice of Forum Clauses in International Contract - A Necessary Problem. International Journal for Legal Developments and Allied Issues, 2(1), 185-196.

Yansen Dermanto Latip. (2002). Pilihan Hukum Dan Pilihan Forum Dalam Kontrak Internasional. Jakarta: Program Pascasarjana Fakultas Hukum Universitas Indonesia.

Peraturan Perundang-undangan:

Kitab Undang-Undang Hukum Perdata. 